\title{
Optimization of Processing Parameters to Achieve Superior Quality and Maximum Recovery of Canola Oil
}

\author{
Hadia Shoaib $^{1}$, Zahid Hussain Laghari ${ }^{1}$, Sarfaraz Ahmed Mahesar ${ }^{1 *}$, Hamide Filiz Ayyildiz ${ }^{2}$, \\ Huseyin Kara ${ }^{3}$, Sirajuddin ${ }^{4}$, Syed Tufail Hussain Sherazi ${ }^{1}$ \\ 1. National Centre of Excellence in Analytical Chemistry, University of Sindh, Jamshoro -76080, Pakistan \\ 2. Selcuk University Faculty of Pharmacy Department of Basic Pharmaceutical Sciences, 42250, \\ Campus-Konya, Turkey \\ 3. Department of Chemistry, Faculty of Science, Selcuk University, 42075, Konya, Turkey \\ 4. International Center for Chemical and Biological Sciences, HEJ Research Institute of Chemistry, University \\ of Karachi, 75270, Pakistan \\ Email: sarfaraz.mahesar@usindh.edu.pk
}

Received: 2 September 2020; Accepted: 22 October 2020; Available online: 20 November 2020

\begin{abstract}
Aim of the present study was to improve the efficiency of processing to achieve a superior quality of canola oil with better recovery. Three sets of canola oil containing crude, neutralized, bleached, deodorized oils and deodorizer distillates (DD) were collected from edible oil processing industries. Important physicochemical properties of the oil were evaluated in all three sets including unsaponifiable matter, phosphorus content and soap content. The industrial processing of set I and II was found to be satisfactory as compared to set III. Therefore, set III was selected for the optimization of different processing parameters during each stage of processing. For neutralization, bleaching and deodorization different parameters were optimized to achieve a better quality of the finished product, good recovery and control of the processing cost. After optimization, physicochemical characteristics of neutralized, bleached, deodorized oil and its DD were evaluated. Also, the loss and recovery of neutral oil were calculated in each processing stage. The results of the present study showed that a slight variation of processing parameters leads to a great impact on the quality and recovery of the canola oil. High contents of free fatty acids (FFA) in DD indicated that it could be used as a potential source of biodiesel production.
\end{abstract}

Keywords: Canola oil; Deodorizer distillate; Optimization; Physiochemical properties; Processing.

\section{Introduction}

Oilseeds are the most important crops all over the world. Over the past 40 years, especially worldwide, canola (Brasica napus) has become the third most important oilseed crop. After soybean oil, canola is the third largest source of vegetable oil in the world [1, 2].

It is considered as healthy edible oil because it contains a very low content of saturated fatty acids (5-7 \%) and high content of polyunsaturated fatty acids with about 7-10 \%, alpha-linolenic and 17-21 \% linoleic acids.

Canola oil extracted from rapeseed which is a bright yellow flower of the Brassicaceae family, grown in the European Union, Unites States, Canada, Australia, China and India [3]. It is an important oil crop species and its cultivation has significantly increased over recent years [4]. Canola oil can be extracted by different methods like pressing and solvent extraction. In the pressing method, the cooked canola seed flakes are pressed in a series of screw presses or expellers. This action removes part of the oil while avoiding excessive pressure and temperature. The objective of pressing is to remove as much oil as possible (usually $50-60 \%$ of the seed oil), while maximizing the output of the expellers and producing a press cake that is ideal for solvent extraction. Since pressing alone cannot remove all of the oil from the canola seed, the press cake is usually solvent extracted to remove the remaining oil. The cake from the expellers contains around18-20\% oil [5]. Almost all commercial canola oil is then extracted using hexane solvent [6, 7].

Refining procedures are indispensable for producing edible oils from most oilseeds such as rapeseed, soybean, sunflower and peanut. Chemical refining, which is composed of degumming, neutralization, bleaching and deodorization, is a widely-used technique in the oil industry to purify edible oils [8]. The initial stage in edible oil processing is degumming which eradicates mainly phospholipids from the oil, traces metal ions and alternative gummy constituents. Phospholipids are oil-soluble, after hydration these are rendered insoluble in oils [9]. 
Neutralization is the second process of chemical refining used to reduce free fatty acid (FFA) from the oil. Generally, in the neutralization process, dilute $\mathrm{NaOH}$ (caustic soda) is used which reacts with FFA (present in the oil) to form salts of fatty acids (soap stock). The developed soapstock from the oil is then removed with water either in the batch method or centrifugation process [10-12].

Generally, bleaching clay is used in the bleaching process next to neutralization and before deodorization of oils. It is an adsorbent procedure to get rid of color pigments, metals, soaps and oxidation products and residual phosphatides from the oil [13].

The endmost step of the refinement of vegetable oils is the deodorization that is responsible for the elimination of volatile components, which are liable for generating unacceptable color, odor, flavor and taste in the oil. These unwanted volatile components such as FFAs, oxidation products of oil and fat specifically ketones, aldehydes, peroxides and alcohols eliminate throughout the deodorization process [14]. At $230-270{ }^{\circ} \mathrm{C}$ temperature and high pressure steam, the volatile odoriferous components present in the oil are stripped off. A high vacuum of about 2 to $8 \mathrm{~mm}$ of $\mathrm{Hg}$ is maintained during deodorizer to avoid the oxidative damage of oil. To control the conditions of outgoing deodorized oil and deodorization value optimized stripping parameters i.e. time, temperature, vacuum, and quantity of stripping steam or nitrogen $\left(\mathrm{N}_{2}\right)$ gas used [14, 15]. In the end, volatile species are collected in the condensed form of deodorizer distillate (DD).

In edible oil refinement, the most vital byproduct is obtained DD in the last step of refining (deodorization stage) [12]. From the deodorization method, volatile fractions are distilled out from the oil and collected in the form of DD through condensers [15-17]. DD is a complex mixture of many health useful components like vitamin E (tocopherols and tocotrienols), squalene and phytosterols. Vitamin E is a major lipid-soluble antioxidant. Furthermore, it contains mono and di-acylglycerols and is considered a cheap source of FFAs [5, 12, 18].

The aim of the present study was to improve the efficiency of processing to achieve a superior quality of canola oil with better recovery.

\section{Materials and methods}

\subsection{Reagents and sample collection}

All the chemicals and reagents were purchased from E-Merck (Darmstadt, Germany), such as n-hexane, methanol, glacial acetic acid, $p$-anisidine, sodium hydroxide, potassium hydroxide, potassium iodide, sodiumthiosulphate pentahydrate, sodium-thiosulphate anhydrous, starch, phenolphthalein, bromophenol blue, hydrochloric acid, carbon tetrachloride, iodine trichloride, ethyl alcohol, sulphuric acid, anhydrous sodium sulphate, and petroleum ether.

Three sets of canola oil samples of crude, neutralized, bleached, deodorized and DD were collected from three different edible oil processing industries in different periods from Karachi and Hyderabad, Pakistan. Fig 1 shows the representative canola oil samples of set III. Three selected industries were of the same production capacity, imported from the same company (Alfalaval) and crushed the same canola seed imported (shipped) from Canada. Collected sets of canola oil samples with their DD samples were kept in the refrigerator at $4^{\circ} \mathrm{C}$ until analysis.

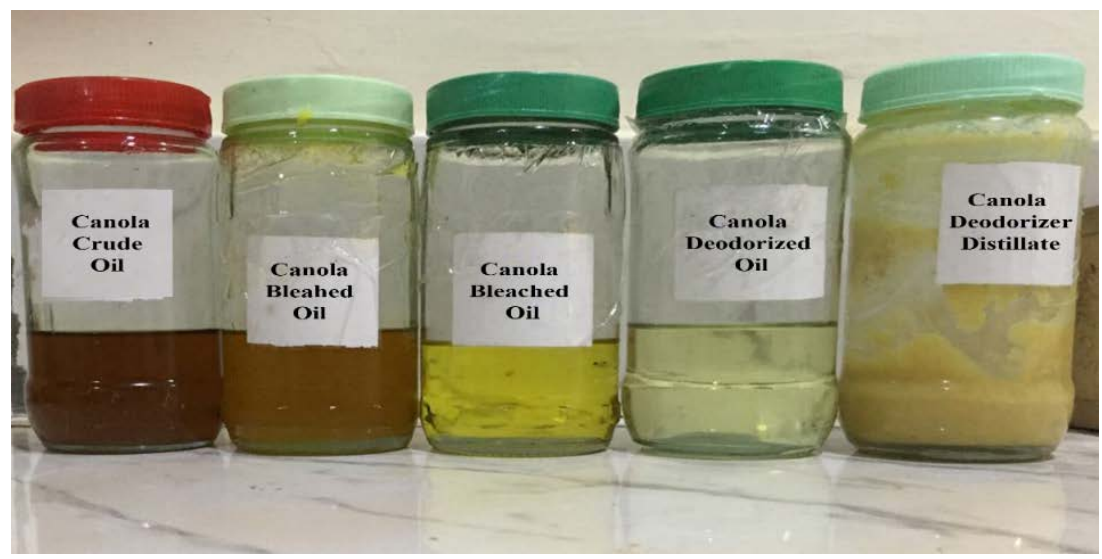

Figure 1. Samples of canola oil set III

\subsection{Physiochemical parameters}

Official AOCS methods were used for the analysis of all physicochemical parameters such as moisture content, color, FFA, Acid value (AV), Peroxide value (PV), p-Anisidine value (p-AV), Total oxidative value (Totox), saponification value (SV), iodine value (IV), unsaponifiable matter, phosphorus content and soap content of the canola oil samples. 
1) Moisture content

Moisture content in canola oil samples and DD was determined by using the official AOCS method Ca 2c-25 [19]. Briefly, $15 \mathrm{~g}$ of canola oil sample was weighed and placed in a Petri dish and heated in the oven (Memmert, Schwabach, Germany) for $30 \mathrm{~min}$ at $130^{\circ} \mathrm{C}$.

2) Color

The color of canola oil samples was check by reported AOCS method Cc 13b-45 [19]. This method is used to determines the color of canola oil samples by comparison with glasses of known color characteristics. Samples of crude oil and DD were placed in 1 inch cell, whereas 5 inch cell was used for neutralized, bleached and deodorized oil samples, respectively and placed in Lovibond Tintometer. The sample color was determined by comparison with standard color slides.

3) Acid value

The AV of canola oil samples was determined by reported AOCS method Cd 3d-63 [19]. Firstly, 20 g of canola oil or $0.1 \mathrm{~g}$ of DD sample was placed in a $250 \mathrm{~mL}$ conical flask. Then, added $150 \mathrm{~mL}$ of an equal ratio of solvent mixture isopropyl alcohol and toluene and $2 \mathrm{~mL}$ of phenolphthalein indicator. Shake the flask continuously and titrating with $0.1 \mathrm{M} \mathrm{KOH}$ solution until the pink color was obtained. Similarly, blank titration was carried out by using the same procedure [14].

4) Free fatty acid

The quantity of FFA in canola oil samples was quantified by using the reported AOCS method Ca 5a-40 [19]. Hot neutralized alcohol $50 \mathrm{~mL}$ with $2 \mathrm{~mL}$ of the indicator was added in $250 \mathrm{~mL}$ conical flask. The mixture was titrated with $0.1 \mathrm{M}$ standard sodium hydroxide solution until the appearance of pink color. About $56 \mathrm{~g}$ of canola oil was added in conical flask and again titrated with sodium hydroxide solution till permanent pink color was the appearance of the same strength as that of the neutralized alcohol before the addition of the sample.

5) Peroxide value

The PV of canola oil samples was determined by reported AOCS method Cd 8-53 [19]. Added $5 \mathrm{~g}$ of canola oil sample in $250 \mathrm{~mL}$ conical flask, and mixed $30 \mathrm{~mL}$ mixture of glacial acetic acid and chloroform ( $3: 2 \mathrm{v} / \mathrm{v})$. The conical flask was constantly shaken to completely dissolve the sample in the solution. About $0.5 \mathrm{~mL}$ of saturated solution of KI was added in a conical flask and shaken occasionally. After this, the solution mixture stands for about $1 \mathrm{~min}$ and added $30 \mathrm{~mL}$ of distilled water. The solution mixture was titrated with $0.1 \mathrm{~N}$ standardized sodium thiosulphate solution till the disappearance of yellow color. Added $0.5 \mathrm{~mL}$ starch indicator (1\%) and titrated with $0.1 \mathrm{~N}$ standardized solution of sodium thiosulphate till the disappearance of blue color.

6) p-Anisidine value

p-AV of canola oil samples or DD was determined by using AOCS method Cd 8-53 [19]. Around, 2 g of canola oil sample or DD was added into $25 \mathrm{~mL}$ volumetric flask and diluted with isooctane. By using UV-Visible spectrophotometer, the absorbance of the sample solution of canola oil or DD was measured at a wavelength of $350 \mathrm{~nm}$. Then, in the test tube, the solution of $5 \mathrm{~mL}$ of canola oil or DD and $1 \mathrm{~mL}$ of p-anisidine was added and left for $10 \mathrm{~min}$. The absorbance of this solution was measured at a wavelength of $350 \mathrm{~nm}$.

7) Total oxidative value

The total oxidative value of the canola oil samples or DD was determined as reported earlier [20] by using the following formula: Totox value $=2 \mathrm{PV}+\mathrm{p}-\mathrm{AV}$.

8) Saponification value

Official AOCS method Cd 3-25 was used for the determination of SV of canola oil samples [19]. About 2 g of oil and $25 \mathrm{~mL}$ of $95 \%$ ethanolic $\mathrm{KOH}$ was added in $50 \mathrm{~mL}$ round bottom flask. The mixture was refluxed for about $30 \mathrm{~min}$. After reflux, the mixture was placed in a $250 \mathrm{~mL}$ conical flask, added few drops of phenolphthalein indicator and titrated with $0.5 \mathrm{~N}$ hydrochloric acid $(\mathrm{HCl})$.

9) Iodine value

Official AOCS method Cd 1-25 was used for the determination of IV in canola oil samples [19]. Around $0.3 \mathrm{~g}$ of sample was placed in a conical flask and added $15 \mathrm{~mL}$ of CCL 3 and $25 \mathrm{~mL}$ of Wij's reagent. The mixture of canola oil sample or DD was kept in dark for $30 \mathrm{~min}$. After that, added $20 \mathrm{~mL}$ of KI solution (10 \%) and $100 \mathrm{~mL}$ of distilled water. The solution mixture was titrated $(0.1 \mathrm{~N})$ with standard sodium thiosulphate solutions using starch (1\%) as an indicator.

10) Unsaponifiable matter

Official AOCS method Ca 6a-40 was used to determine the unsaponifiable matter of canola oil samples [19]. About $5 \mathrm{~g}$ of well mixed test sample of canola oil or DD was taken in $50 \mathrm{~mL}$ round bottom flask, then added 30 $\mathrm{mL}$ of $95 \%$ ethanol and $5 \mathrm{~mL}$ of $50 \%$ solution of potassium hydroxide. Then, this solution was gently boiled and steadily refluxed for $1 \mathrm{~h}$. After reflux, this solution was transferred in the extraction cylinder and washed with 40 $\mathrm{mL}$ solution of $95 \%$ ethanol, $40 \mathrm{~mL}$ distilled water and $5 \mathrm{~mL}$ of petroleum ether. Removed out upper layer and combined in a $500 \mathrm{~mL}$ separating funnel. The extraction procedure repeated six more times by using each time 50 $\mathrm{mL}$ of petroleum ether with continuous shaking. The combined extracts again washed in the separating funnel three times by using $25 \mathrm{~mL}$ of $10 \%$ ethanol solution with vigorous shaking. After shaking, the lower aqueous 
layer was drained out and continued washing practice with $10 \%$ ethanol solution till the washed solution gives no pink color.

11) Phosphorus content

Official AOCS method Ca 12-55 was used for the determination of the phosphorous content in all the samples of canola oil including DD by ashing the samples in the presence of zinc oxide [19]. The specific wavelength of phosphorus $(650 \mathrm{~nm}$ ) was determined as a complex of blue phosphor molybdic acid by the spectrophotometric.

12) Soap content

Reported AOCS Method Cc 17-95 was used for the determination of soap content of canola oil samples or DD [19]. In a test tube, about $40 \mathrm{~g}$ of the sample was taken, then added $1 \mathrm{~mL}$ of water and shaking continuously in a water bath. After that, added $50 \mathrm{~mL}$ of the test solution (contain $0.5 \mathrm{~mL}$ indicator solution bromophenol blue in $100 \mathrm{~mL}$ of acetone and titrated with $0.01 \mathrm{M} \mathrm{HCl}$ till the test solution is just yellow in color) and shaking continuously until two layers formed. The solution was titrated with $0.01 \mathrm{M} \mathrm{HCl}$ till the upper layer showed a permanent yellow color.

\subsection{Statistical analysis}

Three sets of canola oil samples and their DD were collected from three different edible oil industries and examined each parameter three times. The results were evaluated using OriginPro 8 as mean with the standard deviation $(\mathrm{SD})(\mathrm{n}=3 \times 3)$.

\section{Results and discussion}

\subsection{Physiochemical characterization of crude and industrially processed canola oils}

Three sets of canola oil samples collected during different stages of processing were analyzed for their physicochemical characterization. The samples include crude, neutralized, bleached, and deodorized oil. Table 1 represents the results of moisture content, color, FFA, AV, PV, p-AV, Totox, SV, IV, unsaponifiable matter, phosphorus content and soap content in canola oil.

The value provided in the Table 1 are the mean values of triplicate analysis with standard deviation. Means followed by different superscripts in the same column differ significantly (Tukey's test at 0.05 p-level the population are significantly different).

\subsection{Physiochemical characterization of deodorizer distillate of canola oils}

Three samples of canola oil DD were collected from three different edible oil processing industries in different periods from Karachi and Hyderabad, Pakistan. Table 2 represents the results of moisture content, color, FFA, AV, PV, p-AV, Totox, SV, IV, unsaponifiable matter, phosphorus content and soap content in three sets canola oil DD.

The value provided in the Table 2 are the mean values of triplicate analysis with standard deviation. Means followed by different superscripts in the same column differ significantly (Tukey's test at 0.05 p-level the population are significantly different).

\subsection{Optimization of different parameters for neutralization, bleaching and deodorization}

The different processing parameters were optimized for neutralization, bleaching and deodorization to achieve the required quality of oil as well as save time and processing cost. For this, set III was selected to optimize the parameters normally carried out during the refining of edible oil, as this set showed comparatively inferior quality among other sets. The optimization parameters are given below for each processing step.

\subsubsection{Optimization of neutralization}

In the selected edible oil processing industry, chemical neutralization was a separate process from physical refining which includes bleaching and neutralization process. Processing capacities of continuous chemical neutralization process and physical refinery were 200 ton/day.

For the optimization of the neutralization process, the amount of $\mathrm{NaOH}$, temperature, retention time, amount of water and $\mathrm{H}_{3} \mathrm{PO}_{4}$ were varied between $18-22 \%, 50-70{ }^{\circ} \mathrm{C}, 0-5 \mathrm{~min}, 16-24 \%, 0.01-0.1 \%$ and $2-4$ ton/h, respectively in the industry during processing. On the bases of loss, color, soap and phosphorus contents, the optimized values of the neutralization process were found to be $20 \%, 60{ }^{\circ} \mathrm{C}, 3 \mathrm{~min}, 20 \%, 0.05 \%$ and 3 ton/h for the amount of $\mathrm{NaOH}$, temperature, retention time, amount of water and concentration of $\mathrm{H}_{3} \mathrm{PO}_{4}$, respectively. The optimization parameters are shown in Table 3.

\subsubsection{Optimization of bleaching}

Bleaching of canola oil was carried out in the selected industry at a constant vacuum of $2.5 \mathrm{~mm} \mathrm{Hg}$ and flow of $8 \mathrm{ton} / \mathrm{h}$. The values of variables such as temperature, time of bleaching and clay content tested in this study were 
based on the literature [21-23] and previous working experience of the corresponding author in the edible oil processing industries. Table 4 shows the optimization parameters for the bleaching process during refining. Bleaching temperatures (100, 120 and $\left.130{ }^{\circ} \mathrm{C}\right)$, clay amounts (1, 1.5 and $2.5 \%$ ) and flow of oil (7, 8 and 9 ton/h). Bleaching efficiency was monitored by measuring the reduction in color, FFA level and loss of oil. The greatest reduction in red color in bleached oil was achieved using the highest clay content (2.5\%) at the highest temperature $\left(130{ }^{\circ} \mathrm{C}\right)$ but FFA was increased to $0.25 \%$ from $0.21 \%$. Bleaching clay increases oil oxidation due to its greater catalytic activity and high specific area. Therefore, to control the cost of processing and to achieve better recovery of the oil, the optimized parameters for efficient bleaching were clay content $(1.5 \%)$ at the temperature $\left(120{ }^{\circ} \mathrm{C}\right)$ and flow of oil (8 ton/h) as shown in Table 4.

Table 1. Physiochemical properties of crude and industrially processed canola oil set I, II and III

\begin{tabular}{|c|c|c|c|c|}
\hline \multirow[t]{2}{*}{ Parameter } & \multicolumn{4}{|c|}{ Canola Oil } \\
\hline & Crude & Neutralized & Bleached & Deodorized \\
\hline \multirow[t]{3}{*}{ Moisture (\%) } & $0.52 \pm 0.02$ & $0.11 \pm 0.01^{\text {ba }}$ & $0.03 \pm 0.01^{\mathrm{cb}}$ & $0.02 \pm 0.01^{\mathrm{dc}}$ \\
\hline & {$[1.12 \pm 0.07]$} & {$\left[0.12 \pm 0.01^{\mathrm{ba}}\right]$} & {$\left[0.13 \pm 0.01^{\mathrm{cb}}\right]$} & {$\left[0.08 \pm 0.02^{\mathrm{dc}}\right]$} \\
\hline & $\{0.98 \pm 0.03\}$ & $\left\{0.25 \pm 0.02^{\text {ba }}\right\}$ & $\left\{0.22 \pm 0.02^{\mathrm{cb}}\right\}$ & $\left\{0.21 \pm 0.01^{\mathrm{cb}}\right\}$ \\
\hline \multicolumn{5}{|l|}{ Color } \\
\hline \multirow[t]{3}{*}{ Red units (R) } & $5.5 \pm 1.10$ & $4.0 \pm 0.52^{\text {ba }}$ & $1.1 \pm 0.08^{\mathrm{cb}}$ & $0.7 \pm 0.03^{\mathrm{dc}}$ \\
\hline & {$[3.6 \pm 0.63]$} & {$\left[3.5 \pm 0.54^{\mathrm{ba}}\right]$} & {$\left[1.0 \pm 0.07^{\mathrm{ba}}\right]$} & {$\left[0.8 \pm 0.05^{\mathrm{ba}}\right]$} \\
\hline & $\{6.2 \pm 1.42\}$ & $\left\{3.5 \pm 0.24^{\text {ba }}\right\}$ & $\left\{3.0 \pm 0.05^{\text {ba }}\right\}$ & $\left\{1.0 \pm 0.00^{\text {ba }}\right\}$ \\
\hline \multirow[t]{3}{*}{ Yellow units (Y) } & $36 \pm 1.1$ & $30 \pm 1.00^{\text {ba }}$ & $11 \pm 0.50^{\mathrm{cb}}$ & $1.0 \pm 0.03^{\mathrm{dc}}$ \\
\hline & [36 \pm 1.17$]$ & {$\left[30 \pm 0.56^{\mathrm{ba}}\right]$} & {$\left[10 \pm 0.17^{\mathrm{cb}}\right]$} & {$\left[1.0 \pm 0.03^{\mathrm{dc}}\right]$} \\
\hline & $\{70 \pm 2.14\}$ & $\left\{35 \pm 1.34^{\text {ba }}\right\}$ & $\left\{30 \pm 1.33^{\mathrm{cb}}\right\}$ & $\left\{14 \pm 0.84^{\mathrm{dc}}\right\}$ \\
\hline \multirow[t]{3}{*}{ Blue units (B) } & $0.5 \pm 0.02$ & $0.1 \pm 0.01^{\text {ba }}$ & & \\
\hline & {$[0.4 \pm 0.02]$} & {$\left[0.3 \pm 0.02^{\mathrm{ba}}\right]$} & & \\
\hline & $\{1.1 \pm 0.01\}$ & $\left\{0.10 \pm 0.00^{\mathrm{ba}}\right\}$ & & \\
\hline \multirow[t]{3}{*}{ FFA (\%) } & $1.45 \pm 0.15$ & $0.11 \pm 0.02^{\text {ba }}$ & $0.12 \pm 0.01^{\mathrm{cb}}$ & $0.08 \pm 0.01^{\mathrm{dc}}$ \\
\hline & {$[1.32 \pm 0.13]$} & {$\left[0.12 \pm 0.02^{\mathrm{ba}}\right]$} & {$\left[0.13 \pm 0.06^{\mathrm{cb}}\right]$} & {$\left[0.06 \pm 0.04^{\mathrm{dc}}\right]$} \\
\hline & $\{1.91 \pm 0.12\}$ & $\left\{0.22 \pm 0.04^{\text {ba }}\right\}$ & $\left\{0.35 \pm 0.06^{\mathrm{cb}}\right\}$ & $\left\{0.11 \pm 0.02^{\mathrm{dc}}\right\}$ \\
\hline \multirow[t]{3}{*}{ AV (mg KOH/g) } & $2.81 \pm 0.08$ & $0.22 \pm 0.01^{\text {ba }}$ & $0.24 \pm 0.01^{\mathrm{cb}}$ & $0.12 \pm 0.01^{\mathrm{dc}}$ \\
\hline & {$[2.25 \pm 0.02]$} & {$\left[0.25 \pm 0.00^{\mathrm{ba}}\right]$} & {$\left[0.29 \pm 0.01^{\mathrm{cb}}\right]$} & {$\left[0.15 \pm 0.00^{\mathrm{dc}}\right]$} \\
\hline & $\{3.82 \pm 0.09\}$ & $\left\{1.84 \pm 0.05^{\text {ba }}\right\}$ & $\left\{1.83 \pm 0.03^{\mathrm{cb}}\right\}$ & $\left\{0.22 \pm 0.01^{\mathrm{dc}}\right\}$ \\
\hline \multirow[t]{3}{*}{$\mathrm{PV}$ (meqO${ }_{2} / \mathrm{kg}$ ) } & $10.56 \pm 0.36$ & $4.54 \pm 0.25^{\text {ba }}$ & $2.51 \pm 0.09^{c b}$ & $1.73 \pm 0.06^{\mathrm{dc}}$ \\
\hline & {$[8.54 \pm 1.14]$} & {$\left[2.53 \pm 1.08^{\mathrm{ba}}\right]$} & {$\left[1.14 \pm 0.24^{\mathrm{cb}}\right]$} & {$\left[0.55 \pm 0.05^{\mathrm{dc}}\right]$} \\
\hline & $\{11.84 \pm 1.22\}$ & $\left\{6.72 \pm 1.04^{\mathrm{ba}}\right\}$ & $\left\{4.46 \pm 1.01^{\mathrm{cb}}\right\}$ & $\left\{2.85 \pm 0.08^{\mathrm{dc}}\right\}$ \\
\hline \multirow[t]{3}{*}{ p-AV } & $4.29 \pm 0.26$ & $2.63 \pm 0.08^{\text {ba }}$ & $2.11 \pm 0.09^{c b}$ & $1.75 \pm 0.06^{\mathrm{dc}}$ \\
\hline & {$[3.34 \pm 1.09]$} & {$\left[2.26 \pm 0.73^{\mathrm{ba}}\right]$} & {$\left[1.90 \pm 0.01^{\mathrm{cb}}\right]$} & {$\left[1.37 \pm 0.01^{\mathrm{dc}}\right]$} \\
\hline & $\{4.46 \pm 0.09\}$ & $\left\{3.30 \pm 0.07^{\text {ba }}\right\}$ & $\left\{2.56 \pm 0.02^{\mathrm{cb}}\right\}$ & $\left\{2.18 \pm 0.01^{\mathrm{dc}}\right\}$ \\
\hline \multirow[t]{3}{*}{ Totox value } & $14.85 \pm 0.67$ & $7.17 \pm 0.42^{\text {ba }}$ & $4.62 \pm 0.28^{\mathrm{cb}}$ & $3.48 \pm 0.25^{\mathrm{dc}}$ \\
\hline & {$[11.88 \pm 3.08]$} & {$\left[4.79 \pm 1.04^{\mathrm{ba}}\right]$} & {$\left[2.04 \pm 1.02^{\mathrm{ba}}\right]$} & {$\left[1.88 \pm 1.00^{\mathrm{ba}}\right]$} \\
\hline & $\{15.30 \pm 2.06\}$ & $\left\{10.02 \pm 1.22^{\text {ba }}\right\}$ & $\left\{7.00 \pm 0.15^{\text {ba }}\right\}$ & $\left\{5.03 \pm 1.02^{\mathrm{ba}}\right\}$ \\
\hline \multirow[t]{3}{*}{ SV (mgKOH/g) } & $182.6 \pm 5.88$ & $186.5 \pm 7.15^{\text {ba }}$ & $186.2 \pm 5.96^{\mathrm{cb}}$ & $186.1 \pm 6.35^{\mathrm{dc}}$ \\
\hline & {$[181.5 \pm 2.38]$} & {$\left[185.3 \pm 2.35^{\mathrm{ba}}\right]$} & {$\left[185.2 \pm 2.15^{\mathrm{cb}}\right]$} & {$\left[185.1 \pm 2.17^{\mathrm{dc}}\right]$} \\
\hline & $\{186.8 \pm 2.38\}$ & $\left\{189.4 \pm 2.35^{\text {ba }}\right\}$ & $\left\{188.2 \pm 2.35^{\mathrm{cb}}\right\}$ & $\left\{187.7 \pm 2.15^{\mathrm{dc}}\right\}$ \\
\hline \multirow[t]{3}{*}{$\mathrm{IV}\left(\mathrm{gI}_{2} / 100 \mathrm{~g}\right)$} & $118.9 \pm 3.36$ & $112.1 \pm 2.26^{\text {ba }}$ & $115.3 \pm 3.12^{\mathrm{cb}}$ & $106.4 \pm 3.06^{\mathrm{dc}}$ \\
\hline & {$[116.9 \pm 1.19]$} & {$\left[110.9 \pm 1.13^{\mathrm{ba}}\right]$} & {$\left[113.1 \pm 1.03^{\mathrm{cb}}\right]$} & {$\left[105.3 \pm 1.13^{\mathrm{dc}}\right]$} \\
\hline & $\{122.4 \pm 1.19\}$ & $\left\{129.1 \pm 1.13^{\text {ba }}\right\}$ & $\left\{121.1 \pm 1.13^{\mathrm{cb}}\right\}$ & $\left\{118.3 \pm 1.03^{\mathrm{dc}}\right\}$ \\
\hline \multirow{3}{*}{$\begin{array}{l}\text { Unsaponifiable Matter } \\
\text { (\%) }\end{array}$} & $1.36 \pm 0.09$ & $1.96 \pm 0.06^{\text {ba }}$ & $1.56 \pm 0.06^{\mathrm{cb}}$ & $1.32 \pm 0.06^{\mathrm{dc}}$ \\
\hline & {$[1.34 \pm 0.08]$} & {$\left[1.95 \pm 0.07^{\mathrm{ba}}\right]$} & {$\left[1.54 \pm 0.08^{\mathrm{cb}}\right]$} & {$\left[1.32 \pm 0.02^{\mathrm{dc}}\right]$} \\
\hline & $\{1.45 \pm 0.24\}$ & $\left\{1.98 \pm 0.08^{\text {ba }}\right\}$ & $\left\{1.74 \pm 0.07^{\mathrm{cb}}\right\}$ & $\left\{1.58 \pm 0.08^{\mathrm{dc}}\right\}$ \\
\hline \multirow[t]{3}{*}{ Phosphorus content (\%) } & $550 \pm 16.3$ & $132 \pm 5.18^{\text {ba }}$ & $5.92 \pm 1.06^{\mathrm{cb}}$ & $2.64 \pm 1.01^{\mathrm{dc}}$ \\
\hline & {$[492 \pm 11.9]$} & {$\left[183 \pm 4.67^{\mathrm{ba}}\right]$} & {$\left[4.42 \pm 1.08^{\mathrm{cb}}\right]$} & {$\left[3.51 \pm 1.02^{\mathrm{dc}}\right]$} \\
\hline & $\{529 \pm 16.04\}$ & $\left\{252 \pm 8.07^{\text {ba }}\right\}$ & $\left\{5.84 \pm 0.37^{\mathrm{cb}}\right\}$ & $\left\{3.25 \pm 0.18^{\mathrm{dc}}\right\}$ \\
\hline \multirow[t]{3}{*}{ Soap content (ppm ) } & nd & $91.01 \pm 2.34$ & nd & nd \\
\hline & & {$[65.03 \pm 2.28]$} & & \\
\hline & & $\{215 \pm 2.14\}$ & & \\
\hline
\end{tabular}

*Figures in [ ] and \{ \} refers to data for sets II and III, respectively. nd: not detected; a: crude oil; b: neutralized oil; c: bleached oil; d: deodorized oil. 
Table 2. Physiochemical properties of canola oil deodorizer distillate of set I, II and III

\begin{tabular}{|c|c|c|c|c|}
\hline Parameters & Set I & Set II & Set III & Average \\
\hline Moisture content (\%) & $0.28 \pm 0.03^{\mathrm{dd} 2 \mathrm{dd} 1}$ & $0.36 \pm 0.03^{\mathrm{dd} 2 \mathrm{dd} 3}$ & $1.94 \pm 0.07^{\mathrm{dd} 3 \mathrm{dd} 1}$ & 0.86 \\
\hline \multicolumn{5}{|l|}{ Color } \\
\hline Red units (R) & $14.1 \pm 0.52^{\mathrm{dd} 2 \mathrm{dd} 1}$ & $11.1 \pm 0.25^{\mathrm{dd} 2 \mathrm{dd} 3}$ & $19.2 \pm 0.58 \mathrm{dd} 3 \mathrm{dd} 1$ & 14.8 \\
\hline Yellow units (Y) & $71 \pm 2.07^{\text {dd2dd } 1}$ & $71 \pm 2.19^{\mathrm{dd} 2 \mathrm{dd} 3}$ & $92 \pm 2.81$ dd3dd 1 & 78 \\
\hline Blue units (B) & $0.1 \pm 0.00^{\mathrm{dd} 2 \mathrm{dd} 1}$ & $2.0 \pm 0.38^{\mathrm{dd} 2 \mathrm{dd} 3}$ & $1.0 \pm 0.00 \mathrm{dd} 3 \mathrm{dd} 1$ & 1.0 \\
\hline FFA (\%) & $59.2 \pm 2.11^{\mathrm{dd} 2 \mathrm{dd} 1}$ & $52.4 \pm 1.55^{\mathrm{dd} 2 \mathrm{dd} 3}$ & $63.5 \pm 1.78$ dd3dd 1 & 58.4 \\
\hline $\mathrm{AV}$ (mg KOH/g) & $118.6 \pm 4.75^{\mathrm{dd} 2 \mathrm{dd} 1}$ & $104.8 \pm 2.15^{\mathrm{dd} 2 \mathrm{dd} 3}$ & $126.8 \pm 5.54$ dd3dd 1 & 116.7 \\
\hline $\mathrm{PV}\left(\mathrm{meqO}_{2} / \mathrm{kg}\right)$ & $6.84 \pm 0.12^{\mathrm{dd} 2 \mathrm{dd} 1}$ & $5.92 \pm 0.22^{\mathrm{dd} 2 \mathrm{dd} 3}$ & $7.52 \pm 0.35$ dd $3 \mathrm{dd} 1$ & 6.76 \\
\hline $\mathrm{p}-\mathrm{AV}$ & $5.67 \pm 0.28 \mathrm{dd} 2 \mathrm{dd} 1$ & $5.23 \pm 0.24 \mathrm{dd} 2 \mathrm{dd} 3$ & $6.42 \pm 0.30$ dd $3 \mathrm{dd} 1$ & 5.77 \\
\hline Totox value & $19.4 \pm 0.88^{\mathrm{dd} 2 \mathrm{dd} 1}$ & $17.1 \pm 0.76 \mathrm{dd} 2 \mathrm{dd} 3$ & $21.4 \pm 0.43^{\text {dd } 3 \mathrm{dd} 1}$ & 19.3 \\
\hline SV (mgKOH/g) & $165.5 \pm 6.40^{\mathrm{dd} 2 \mathrm{dd} 1}$ & $161.3 \pm 6.35 \mathrm{dd} 2 \mathrm{dd} 3$ & $184.5 \pm 6.45$ dd $3 \mathrm{dd} 1$ & 170.4 \\
\hline $\mathrm{IV}\left(\mathrm{gI}_{2} / 100 \mathrm{~g}\right)$ & $99.9 \pm 4.36$ dd2dd 1 & $99.9 \pm 3.91$ dd2dd3 & $104.9 \pm 4.23^{\text {dd } 3 \mathrm{dd} 1}$ & 101.6 \\
\hline Unsaponifiable Matter (\%) & $17.1 \pm 0.49$ dd $2 \mathrm{dd} 1$ & $18.2 \pm 0.64 \mathrm{dd} 2 \mathrm{dd} 3$ & $19.4 \pm 0.71$ dd3dd 1 & 18.2 \\
\hline Phosphorus content (mg/kg) & nd & nd & nd & nd \\
\hline Soap content (ppm) & nd & nd & nd & nd \\
\hline
\end{tabular}

*nd: not detected; dd1=set I, dd2=set II and dd3= set III.

Table 3. Optimization parameters for neutralization process during the refining

\begin{tabular}{|c|c|c|c|c|c|}
\hline \multirow{2}{*}{$\begin{array}{r}\text { Parameters } \\
\mathrm{NaOH}(\%)\end{array}$} & \multicolumn{5}{|c|}{ Results } \\
\hline & 18 & FFA (\%) & 0.3 & Loss (\%) & 2 \\
\hline & 20 & & 0.2 & & 2 \\
\hline & 22 & & 0.2 & & 2.5 \\
\hline \multirow[t]{3}{*}{ Temperature $\left({ }^{\circ} \mathrm{C}\right)$} & 50 & FFA (\%) & 0.35 & Color (R) & 3.5 \\
\hline & 60 & & 0.2 & & 3.0 \\
\hline & 70 & & 0.24 & & 4.0 \\
\hline \multirow[t]{3}{*}{ Retention time (min) } & 0 & FFA (\%) & 0.3 & Color (R) & 3.5 \\
\hline & 3 & & 0.2 & & 3.0 \\
\hline & 5 & & 0.2 & & 3.0 \\
\hline \multirow[t]{3}{*}{ Water (\%) } & 16 & FFA (\%) & 0.2 & Soap (ppm) & 216 \\
\hline & 20 & & 0.2 & & 51 \\
\hline & 24 & & 0.2 & & 51 \\
\hline \multirow[t]{3}{*}{$\mathrm{H}_{3} \mathrm{PO}_{4}(\%)$} & 0.01 & FFA (\%) & 0.2 & Phosphorus (ppm) & 200 \\
\hline & 0.05 & & 0.2 & & 45 \\
\hline & 0.1 & & 0.3 & & 10 \\
\hline \multirow[t]{3}{*}{ Flow of oil (ton/h) } & 2 & FFA (\%) & 0.2 & Color (R) & 3.0 \\
\hline & 3 & & 0.2 & & 3.0 \\
\hline & 4 & & 0.3 & & 4.0 \\
\hline
\end{tabular}

Table 4. Optimization parameters for bleaching process during the refining

\begin{tabular}{|c|c|c|c|c|c|}
\hline \multicolumn{2}{|l|}{ Parameters } & \multicolumn{4}{|c|}{ Results } \\
\hline \multirow[t]{3}{*}{ Bleaching clay (\%) } & 1 & Color (R) & 1.5 & FFA (\%) & 0.21 \\
\hline & 1.5 & & 1.0 & & 0.23 \\
\hline & 2.5 & & 0.9 & & 0.25 \\
\hline \multirow[t]{3}{*}{ Temperature $\left({ }^{\circ} \mathrm{C}\right)$} & 100 & Color (R) & 1.2 & FFA (\%) & 0.23 \\
\hline & 120 & & 1.0 & & 0.23 \\
\hline & 130 & & 1.3 & & 0.26 \\
\hline \multirow[t]{3}{*}{ Flow of oil (ton/h) } & 7 & Color (R) & 1.0 & FFA (\%) & 0.23 \\
\hline & 8 & & 1.0 & & 0.23 \\
\hline & 9 & & 1.4 & & 0.28 \\
\hline
\end{tabular}

\subsubsection{Optimization of deodorization}

Deodorization is an important step in refining since numerous processing parameters such as vacuum, temperature, the flow of oil and strapping steam affect the deodorization process. For the optimization of the deodorization process vacuum, temperature, flow of oil and strapping steam were varied in the industry during processing for constant time (35 min). The optimized values of vacuum, temperature, the flow of oil and strapping steam were $2.5 \mathrm{mmHg}, 250{ }^{\circ} \mathrm{C}, 8 \mathrm{ton} / \mathrm{h}$ and $3 \%$, respectively. The optimization parameters are shown in Table 5 . 
Table 5. Optimization parameters for deodorization process during the refining

\begin{tabular}{|c|c|c|c|c|c|}
\hline \multicolumn{2}{|c|}{ Parameters } & \multicolumn{4}{|c|}{ Results } \\
\hline \multirow[t]{3}{*}{ Vacuum (mmHg) } & 2 & Color (R) & 0.5 & FFA (\%) & 0.12 \\
\hline & 2.5 & & 0.06 & & 0.04 \\
\hline & 3 & & 0.16 & & 0.04 \\
\hline \multirow[t]{3}{*}{ Temperature $\left({ }^{\circ} \mathrm{C}\right)$} & 240 & Color (R) & 0.5 & FFA (\%) & 0.15 \\
\hline & 250 & & 0.06 & & 0.04 \\
\hline & 260 & & 0.09 & & 0.07 \\
\hline \multirow[t]{3}{*}{ Flow of oil (ton/h) } & 7 & Color (R) & 0.06 & FFA (\%) & 0.04 \\
\hline & 8 & & 0.06 & & 0.04 \\
\hline & 9 & & 0.12 & & 1.10 \\
\hline \multirow[t]{3}{*}{ Stripping steam (\%) } & 2 & Color (R) & 0.4 & FFA (\%) & 0.25 \\
\hline & 3 & & 0.06 & & 0.04 \\
\hline & 4 & & 0.06 & & 0.04 \\
\hline Time constant (min) & 35 & Color (R) & 0.06 & FFA (\%) & 0.04 \\
\hline
\end{tabular}

\subsection{Impact of processing stages on the recovery and loss of canola oil and deodorizer distillate}

When 100 ton canola oil was neutralized then total neutralized oil recovery was $98 \%$ with the loss of $2 \%$. During bleaching, the recovery was found to be $98.6 \%$ with a neutral oil loss of $0.3 \%$. During deodorization, the deodorized oil was recovered by $99.5 \%$ with the recovery of $0.5 \%$ DD. Total processing loss from crude to deodorized oil including neutralization, bleaching and Deodorization was found to be $2.8 \%$ and with the recovery of $97.2 \%$ deodorized oil as shown in Table 6.

Table 6. Recovery and loss of canola oil and deodorizer distillate

\begin{tabular}{lcccc}
\hline Processing stages & Processed (ton) & Recovered (ton) & Recovery (\%) & Loss (\%) \\
\hline Neutralization process & 100 & 98 & 98 & 2 \\
Bleaching process & 98 & 97.7 & 99.6 & 0.4 \\
Deodorization process & 97.7 & 97.2 & 99.5 & 0.5 \\
Total processing & 100 & $0.5(\mathrm{DD})$ & & \\
\end{tabular}

\subsection{Physiochemical properties of crude and industrially processed canola oil before and after optimization}

Table 7 shows the physicochemical properties of crude and industrially processed canola oil set III before and after optimization. Before optimization, the moisture content of crude canola oil in set III was found at $0.98 \%$. In the neutralization step, the moisture content before optimization was found to be $0.25 \%$ but after optimization moisture content was reduced 0.25 to $0.03 \%$. In bleaching and deodorization steps during optimization, the moisture content decreased further as compared to the before optimization. During optimization, the color of crude canola oil was found $6.2 \mathrm{R}, 70 \mathrm{Y}$ and $1.1 \mathrm{~B}$. Before optimization of neutralization, bleaching and deodorization step the color of oil continuously decreased but after optimization, the color of canola oil was reduced more in each refining steps 3.5 to $3.0 \mathrm{R}, 35$ to $32 \mathrm{Y}$ and 0.1 to $0.0 \mathrm{~B}$ in neutralized oil, 3.0 to $1.0 \mathrm{R}$ and 30 to $10 \mathrm{Y}$ in bleached oil and 1.0 to $0.6 \mathrm{R}, 14$ to $6.0 \mathrm{Y}$ in deodorized oil, respectively. The FFA of crude canola oil before optimization was found $1.91 \%$ in set III. During the optimization of neutralization, bleaching and deodorization step the FFA was continuously decreased. After the optimization the FFA value of neutralization, bleaching and deodorization steps were reduced more 0.22 to $0.09 \%, 0.35$ to $0.13 \%$ and 0.11 to $0.04 \%$, respectively. The AV of crude canola oil before optimization was found $3.82 \%$ in set III. During the optimization of neutralization, bleaching and deodorization step the AV was continuously decreased. After the optimization, the AV of neutralization, bleaching and deodorization steps were reduced from 1.48 to $1.32 \mathrm{mgKOH} / \mathrm{g}, 1.83$ to 1.73 $\mathrm{mgKOH} / \mathrm{g}$ and 0.20 to $0.09 \mathrm{mgKOH} / \mathrm{g}$, respectively.

Before optimization, the PV of crude canola oil in set III was found $11.84 \mathrm{meqO}_{2} / \mathrm{kg}$. In neutralization, bleaching and deodorization steps during optimization the PV was decreased to 1.99, 1.86 and 0.00 meqO $/ 2 \mathrm{~kg}$, respectively. In the deodorization stage maximum PV was decreased (100\%). Before optimization, the p-AV of crude canola oil in set III was found 4.46. In neutralization, bleaching and deodorization steps during optimization the p-AV was highly decreased to 2.26, 1.94 and 0.53, respectively. Major reduction (72.68 \%) was observed during the deodorization process. Before optimization, the totox value of crude canola oil in set III was found at 15.30. In neutralization, bleaching and deodorization steps during optimization, the totox value was further minimized as compared to the values before optimization. After optimization, the totox value of neutralization, bleaching and deodorization steps were found 6.24, 5.66 and 0.53 , respectively. In set III, the SV of crude canola 
oil before optimization was found at $186.8 \mathrm{mgKOH} / \mathrm{g}$. In neutralization, bleaching and deodorization steps during optimization the SV was slightly decreased as compared to the before optimization. The IV and unsaponifiable matter of crude canola oil in set III before optimization was found $122.4 \mathrm{gI}_{2} / 100 \mathrm{~g}$ and $1.45 \%$, respectively. During optimization, in the neutralization, bleaching and deodorization step the IV and unsaponifiable matter were slightly decreased as compared to the before optimization. The phosphorus content of crude canola oil before optimization was found at $529 \mathrm{mg} / \mathrm{kg}$ in set III. During the optimization of neutralization, bleaching and deodorization step the phosphorus content was continuously decreased. The phosphorus content before and after optimization of neutralization, bleaching and deodorization steps were determined as 252 to $45 \mathrm{mg} / \mathrm{kg}, 5.84$ to $4.18 \mathrm{mg} / \mathrm{kg}$ and 3.25 to $0.00 \mathrm{mg} / \mathrm{kg}$, respectively. Soap content was only found in the neutralized oil. Before optimization, the soap content was found 215 ppm, but after optimization, the soap content was decreased from 215 ppm to 51 ppm.

The value provided in Table 7 is the mean values of triplicate analysis with standard deviation. Means followed by different superscripts in the same column differ significantly (Tukey's test at 0.05 p-level the population is significantly different).

Table 7. Physiochemical properties of crude and industrially processed canola oil set III before and after optimization

\begin{tabular}{|c|c|c|c|c|c|c|c|}
\hline \multirow{2}{*}{ Samples } & \multirow{2}{*}{ Crude oil } & \multicolumn{2}{|c|}{ Neutralized oil } & \multicolumn{2}{|c|}{ Bleached oil } & \multicolumn{2}{|c|}{ Deodorized oil } \\
\hline & & Before & After & Before & After & Before & After \\
\hline $\begin{array}{l}\text { Moisture } \\
\text { content (\%) }\end{array}$ & $0.98 \pm 0.03$ & $0.25 \pm 0.02^{\mathrm{a} 2 \mathrm{a} 1}$ & $0.03 \pm 0.01$ & $0.22 \pm 0.02^{\mathrm{b} 2 \mathrm{~b} 1}$ & $0.02 \pm 0.01$ & $0.21 \pm 0.01^{\mathrm{c} 2 \mathrm{c} 1}$ & $0.01 \pm 0.01$ \\
\hline \multicolumn{8}{|l|}{ Color } \\
\hline Red units (R) & $6.2 \pm 1.42$ & $3.5 \pm 0.24^{\mathrm{a} 2 \mathrm{a} 1}$ & $3.0 \pm 0.15$ & $3.0 \pm 0.05^{\mathrm{b} 2 \mathrm{~b} 1}$ & $1.0 \pm 0.00$ & $1.0 \pm 0.00^{\mathrm{c} 2 \mathrm{c} 1}$ & $0.6 \pm 0.02$ \\
\hline $\begin{array}{l}\text { Yellow units } \\
(\mathrm{Y})\end{array}$ & $70 \pm 2.14$ & $35 \pm 1.34^{\mathrm{a} 2 \mathrm{a} 1}$ & $32 \pm 1.53$ & $30 \pm 1.33^{\mathrm{b} 2 \mathrm{~b} 1}$ & $10 \pm 0.12$ & $14 \pm 0.58^{\mathrm{c} 2 \mathrm{c} 1}$ & $6.0 \pm 0.36$ \\
\hline Blue units (B) & $1.1 \pm 0.01$ & $0.10 \pm 0.00^{\mathrm{a} 2 \mathrm{a} 1}$ & nd & nd & nd & nd & nd \\
\hline FFA (\%) & $1.91 \pm 0.12$ & $0.22 \pm 0.04^{\mathrm{a} 2 \mathrm{a} 1}$ & $0.09 \pm 0.01$ & $0.35 \pm 0.06^{\mathrm{b} 2 \mathrm{~b} 1}$ & $0.13 \pm 0.01$ & $0.11 \pm 0.02^{\mathrm{c} 2 \mathrm{c} 1}$ & $0.04 \pm 0.01$ \\
\hline $\begin{array}{l}\text { AV (mg } \\
\mathrm{KOH} / \mathrm{g})\end{array}$ & $3.82 \pm 0.09$ & $1.84 \pm 0.05^{\mathrm{a} 2 \mathrm{a} 1}$ & $1.32 \pm 0.02$ & $1.83 \pm 0.03^{\mathrm{b} 2 \mathrm{~b} 1}$ & $1.73 \pm 0.02$ & $0.22 \pm 0.01^{\mathrm{c} 2 \mathrm{c} 1}$ & $0.08 \pm 0.01$ \\
\hline $\mathrm{PV}\left(\mathrm{meqO}_{2} / \mathrm{kg}\right)$ & $11.84 \pm 1.22$ & $6.72 \pm 1.04^{\mathrm{a} 2 \mathrm{a} 1}$ & $1.99 \pm 0.02$ & $4.46 \pm 1.01^{\mathrm{b} 2 \mathrm{~b} 1}$ & $1.86 \pm 0.02$ & $2.85 \pm 0.08^{\mathrm{c} 2 \mathrm{c} 1}$ & nd \\
\hline $\begin{array}{l}\text { p-Anisidine } \\
\text { value }\end{array}$ & $4.46 \pm 0.09$ & $3.30 \pm 0.07^{\mathrm{a} 2 \mathrm{a} 1}$ & $2.26 \pm 0.01$ & $2.56 \pm 0.02^{\mathrm{b} 2 \mathrm{~b} 1}$ & $1.94 \pm 0.03$ & $2.18 \pm 0.01^{\mathrm{c} 2 \mathrm{c} 1}$ & $0.53 \pm 0.01$ \\
\hline Totox value & $15.30 \pm 2.06$ & $10.02 \pm 1.22^{\mathrm{a} 2 \mathrm{a} 1}$ & $6.24 \pm 0.01$ & $7.00 \pm 0.15^{\mathrm{b} 2 \mathrm{~b} 1}$ & $5.66 \pm 0.13$ & $5.03 \pm 1.02^{\mathrm{c} 2 \mathrm{c} 1}$ & $0.53 \pm 0.02$ \\
\hline $\begin{array}{l}\text { SV } \\
\text { (mgKOH/g) }\end{array}$ & $186.8 \pm 2.38$ & $189.4 \pm 2.35^{\mathrm{a} 2 \mathrm{a} 1}$ & $186.4 \pm 2.15$ & $188.2 \pm 2.35^{\mathrm{b} 2 \mathrm{~b} 1}$ & $185.4 \pm 1.15$ & $187.7 \pm 2.15^{\mathrm{c} 21}$ & $185.4 \pm 2.16$ \\
\hline $\mathrm{IV}\left(\mathrm{gI}_{2} / 100 \mathrm{~g}\right)$ & $122.4 \pm 1.19$ & $129.1 \pm 1.13^{\mathrm{a} 2 \mathrm{a} 1}$ & $117.1 \pm 1.06$ & $121.1 \pm 1.13^{\mathrm{b} 2 \mathrm{~b} 1}$ & $105.2 \pm 1.10$ & $118.3 \pm 0.06^{\mathrm{c} 2 \mathrm{c} 1}$ & $101.3 \pm 2.06$ \\
\hline $\begin{array}{l}\text { Unsaponifiabl } \\
\text { e Matter (\%) }\end{array}$ & $1.45 \pm 0.24$ & $1.98 \pm 0.08^{\mathrm{a} 2 \mathrm{a} 1}$ & $1.61 \pm 0.07$ & $1.74 \pm 0.01^{\mathrm{b} 2 \mathrm{~b} 1}$ & $1.52 \pm 0.01$ & $1.58 \pm 0.08^{\mathrm{c} 2 \mathrm{c} 1}$ & $1.30 \pm 0.01$ \\
\hline $\begin{array}{l}\text { Phosphorus } \\
\text { content } \\
\text { (mg/kg) }\end{array}$ & $529 \pm 16.04$ & $252 \pm 8.07^{\mathrm{a} 2 \mathrm{a} 1}$ & $45 \pm 3.06$ & $5.84 \pm 0.37^{\mathrm{b} 2 \mathrm{~b} 1}$ & $4.18 \pm 0.42$ & $3.25 \pm 0.18^{\mathrm{c} 2 \mathrm{c} 1}$ & nd \\
\hline $\begin{array}{l}\text { Soap content } \\
\text { (ppm ) }\end{array}$ & nd & $215 \pm 2.14^{\mathrm{a} 2 \mathrm{a} 1}$ & $51 \pm 2.06$ & nd & nd & nd & nd \\
\hline
\end{tabular}

\subsection{Physiochemical properties of deodorizer distillate of canola oil before and after optimization}

Table 8 shows the physicochemical properties of canola oil DD before and after optimization. Before optimization, the moisture content in DD of canola oil in set III was found $1.94 \%$, but after the optimization, the moisture content was decreased further from 1.94 to $0.03 \%$. Similarly, the rest of the parameters such as color, FFA, AV, PV, p-AV, Totox value, SV, IV and unsaponifiable matter was exceedingly decreased after optimization. Before optimization color, FFA, AV, PV, p-AV, Totox value, SV, IV and unsaponifiable matter were found to be 19.2 R, $92 \mathrm{Y}$ and $1.0 \mathrm{~B}, 63.5$ \%, $126.9 \mathrm{mgKOH} / \mathrm{g}, 7.52 \mathrm{meqO}_{2} / \mathrm{kg}, 6.42,21.4,184.5 \mathrm{mgKOH} / \mathrm{g}, 104.9$ gI $/ 2 / 100 \mathrm{~g}$, $19.4 \%$, respectively. But after optimization these values further reduced $12.0 \mathrm{R}, 60 \mathrm{Y}$ and $0.1 \mathrm{~B}, 50.5 \%, 116.4$ $\mathrm{mgKOH} / \mathrm{g}, 6.52 \mathrm{meqO}_{2} / \mathrm{kg}, 5.63,18.7,163.2 \mathrm{mgKOH} / \mathrm{g}, 98.2 \mathrm{gI}_{2} / 100 \mathrm{~g}, 19.2 \%$, respectively. The phosphorus content and soap content in DD of canola oil before and after optimization were not determined. 
The value provided in Table 8 is the mean values of triplicate analysis with standard deviation. Means followed by different superscripts in the same column differ significantly (Tukey's test at 0.05 p-level the population is significantly different).

Table 8. Physiochemical properties of canola oil deodorizer distillate before and after optimization

\begin{tabular}{lcc}
\hline Parameters & Before optimization & After optimization \\
\hline Moisture content (\%) & $1.94 \pm 0.07^{\mathrm{a} 2 \mathrm{a} 1}$ & $0.03 \pm 0.00$ \\
Color & $19.2 \pm 0.58^{\mathrm{a} 2 \mathrm{a} 1}$ & \\
Red units (R) & $92 \pm 2.81^{\mathrm{a} 2 \mathrm{a} 1}$ & $12.0 \pm 0.33$ \\
Yellow units (Y) & $1.0 \pm 0.00^{\mathrm{a} 2 \mathrm{a} 1}$ & $60 \pm 3.02$ \\
Blue units (B) & $63.5 \pm 1.78^{\mathrm{a} 2 \mathrm{a} 1}$ & $0.1 \pm 0.01$ \\
FFA (\%) & $126.9 \pm 5.54^{\mathrm{a} 2 \mathrm{a} 1}$ & $50.5 \pm 2.12$ \\
AV (mg KOH/g) & $7.52 \pm 0.35^{\mathrm{a} 2 \mathrm{a} 1}$ & $116.4 \pm 5.03$ \\
PV (meqO$/ \mathrm{kg})$ & $6.42 \pm 0.30^{\mathrm{a} 2 \mathrm{a} 1}$ & $6.52 \pm 0.27$ \\
p-AV & $21.4 \pm 0.43^{\mathrm{a} 2 \mathrm{a} 1}$ & $5.63 \pm 0.27$ \\
Totox value & $184.5 \pm 6.45^{\mathrm{a} 2 \mathrm{a} 1}$ & $18.7 \pm 0.65$ \\
SV (mgKOH/g) & $104.9 \pm 4.23^{\mathrm{a} 2 \mathrm{a} 1}$ & $163.2 \pm 6.05$ \\
IV (gI $/ 100 \mathrm{~g})$ & $19.4 \pm 0.71^{\mathrm{a} 2 \mathrm{a} 1}$ & $98.2 \pm 3.89$ \\
Unsaponifiable Matter (\%) & nd & $19.2 \pm 0.67$ \\
Phosphorus content (mg/kg) & nd & $\mathrm{nd}$ \\
Soap content $(\%)$ & $\mathrm{nd}$ \\
\hline
\end{tabular}

*nd: not detected; a1: before optimization; a2: after optimization.

\section{Conclusions}

Impacts of processing such as neutralization, bleaching and deodorization on the physicochemical parameters of canola oil and canola oil DD of three different industries were evaluated. The processing of two industries was found to be satisfactory while processing parameters of each stage for the third industry were optimized to improve the efficiency of the individual process. Optimized parameters of each processing stage lead to the acceptable quality of oil, minimum processing loss and cost at constant production. Best of our knowledge it is the first time that processing parameters are optimized within the industry and to observe that all physicochemical properties of oil changed after optimization on each process (neutralization, bleaching and deodorization). High amounts of FFA in DD samples indicating that it could be used for the production of biodiesel and oleochemicals. It also contains a significant amount of unsaponifiable part which comprise of many useful components such as sterols and tocopherols. Therefore, the unsaponifiable part of canola oil DD can be utilized as a natural source of bioactive components for food, cosmetic and pharmaceutical industries.

\section{References}

[1] Ali AH, Zou X, Abed SM, Korma SA, Jin Q, Wang X. Natural phospholipids: Occurrence, biosynthesis, separation, identification, and beneficial health aspects. Critical Reviews in Food Science and Nutrition. 2019;59(2):253-275.

[2] Baux A, Hebeisen T, Pellet D. Effects of minimal temperatures on low-linolenic rapeseed oil fatty-acid composition. European Journal of Agronomy. 2008;29(2-3):102-107.

[3] Beyzi E, Gunes A, Beyzi SB, Konca Y. Changes in fatty acid and mineral composition of rapeseed (Brassica napus ssp. oleifera L.) oil with seed sizes. Industrial Crops and Products. 2019;129:10-14.

[4] Bowen KJ, Kris-Etherton PM, West SG, Fleming JA, Connelly PW, Lamarche B, Hammad SS. Diets enriched with conventional or high-oleic acid canola oils lower atherogenic lipids and lipoproteins compared to a diet with a western fatty acid profile in adults with central adiposity. The Journal of nutrition. 2019;149(3):471-478.

[5] Chu BS, Baharin BS, Quek SY. Factors affecting pre-concentration of tocopherols and tocotrienols from palm fatty acid distillate by lipase-catalysed hydrolysis. Food Chemistry. 2002;79(1):55-59.

[6] DeBonte L, Iassonova D, Liu L, Loh W. Commercialization of high oleic canola oils. Lipid Technology. 2012;24(8); 175-177.

[7] Dumont MJ, Narine SS. Characterization of flax and soybean soapstocks, and soybean deodorizer distillate by GC-FID. Journal of the American Oil Chemists' Society. 2007;84(12):1101-1105.

[8] Farahmandfar R, Ramezanizadeh MH. Oxidative stability of canola oil by Biarum bovei bioactive components during storage at ambient temperature. Food Science \& Nutrition. 2018;6(2):342-347. 
[9] Frankel EN. Lipid oxidation. Oily Press Lipid. Bridgwater, UK. 2005.

[10] Firestone D. Official methods and recommended practices of the AOCS. AOCS (American Oil Chemists' Society). Urbana, IL. 2013.

[11] Gaber MAFM, Trujillo FJ, Mansour MP, Taylor C, Juliano P. Megasonic-assisted aqueous extraction of canola oil from canola cake. Journal of Food Engineering. 2019;252:60-68.

[12] Hawkes C, Friel S, Lobstein T, Lang T. Linking agricultural policies with obesity and noncommunicable diseases: a new perspective for a globalising world. Food Policy. 2012;37(3):343-353.

[13] Naz S, Kara H, Sherazi STH, Aljabour A, Talpur FN. A green approach for the production of biodiesel from fatty acids of corn deodorizer distillate. RSC Advances. 2014;4(89):48419-48425.

[14] Shahbazi Y, Shavisi N. Effect of methanolic Prosopis farcta extract on storage stabilization of canola oil. Journal of Food Science and Technology. 2019;56(1):420-427.

[15] Ren X, Wang L, Xu B, Wei B, Liu Y, Zhou C, Wang Z. Influence of microwave pretreatment on the flavor attributes and oxidative stability of cold-pressed rapeseed oil. Drying Technology. 2019;37(3):397-408.

[16] Ruiz-Méndez MV, Dobarganes MC. Combination of chromatographic techniques for the analysis of complex deodoriser distillates from an edible oil refining process. Food Chemistry. 2007;103(54):1502-1507.

[17] Yu D, Ma Y, Jiang L, Elfalleh W, Shi M, Hu L. Optimization of magnetic immobilized phospholipase A 1 degumming process for soybean oil using response surface methodology. European Food Research and Technology. 2013;237(5):811-817.

[18] Kamboh MA, Chang AS, Ibrahim WAW, Sanagi MM, Mahesar SA, Sherazi STH. A green method for the quantitative assessment of neutral oil in palm fatty acid distillates by single bounce attenuated total reflectance Fourier-transform infrared spectroscopy. RSC Advances. 2015;5(62):50591-50596.

[19] Shoaib H, Mahesar SA, Jafarian P, Niazmand R, Sherazi STH. Quality evaluation of canola oils and deodorizer distillate during industrial processing. Journal of the Chemical Society of Pakistan.2019;41(6):983.

[20] Naz S, Sherazi STH, Talpur FN, Talpur MY, Kara H. Determination of unsaponifiable constituents of deodorizer distillates by GC-MS. Journal of the American Oil Chemists' Society. 2012;89(6):973-977.

[21] Wang T. Soybean oil. vegetable oils food technology- Composition, properties and uses. Blackwell Publishing Ltd. Oxford, UK, 2002.

[22] Moreda W, Pérez Camino MC, Cert A. Analysis of neutral lipids: Unsaponifiable, in Nollet LML (Ed.) Handbook of Food Analysis. Marcel Dekker, Inc, New York. 2004.

[23] Zschau W. Bleaching of edible fats and oils. European Journal of Lipid Science and Technology. 2001;103(8):505-551.

(C) 2020 by the author(s). This work is licensed under a Creative Commons Attribution 4.0 International License (http://creativecommons.org/licenses/by/4.0/). Authors retain copyright of their work, with first publication rights granted to Tech Reviews Ltd. 